\title{
The Motivation and Characteristic of Students Studying Helping Major with Specialization on Special Pedagogic and Social Work
}

\author{
Lukáš Stárek \\ Department of Special Education, Univerzita Jana Amose Komenského Praha s.r.o., Roháčova 63 \\ Prague 3130 00, Prag, Czech Republic
}

\begin{abstract}
This paper presents the view of university students who are specialized in helping professions - in this case, special pedagogues and social workers. 501 respondents participated in this research. This article presents respondents' characteristic, their motivation to study this major and investigate in the employability of students in relation to their professional identity. The aims are to presents students' opinions, and to highlight the necessity of professional preparation i.e., placement during pre-graduate courses in the career of special pedagogues and social workers.
\end{abstract}

Keywords - characteristic, helping professions motivation, practical training, student.

\section{Introduction}

The life aspects cause that every human being is facing to diverse social factors such as environment, people, groups, culture, political factors. These factors influence not only growing up but the rest of their life, and their choice of profession as well.

"Human is social creature, the level of their social development has a significant influence on their quality of life, individual mindset, and the life path they choose" [1].

DOI: $10.18421 /$ TEM111-05

https://doi.org/10.18421/TEM111-05

Corresponding author: Lukáš Stárek, Department of Special Education, Univerzita Jana Amose Komenského Praha s.r.o., Prague, Czech Republic.

Email: starek.lukas@ujak.cz

Received: 29 October 2021.

Revised: 10 January 2022.

Accepted: 17 January 2022.

Published: 28 February 2022.

(cc) BY-NC-ND (C) 2022 Lukáš Stárek; published by UIKTEN. This work is licensed under the Creative Commons Attribution-NonCommercial-NoDerivs 4.0 License.

The article is published with Open Access at https://www.temjournal.com/
The character can be defined as an identity that signalizes belonging to some category such as gender, nationality, profession. The basic categorizing is physical, social, and psychological. Into the physical category fits gender, fingerprint, body proportion, scarfs etc. As social identity is defined by social roles i.e., mother, daughter. Finally, the psychological identity is an original character that belongs to the concrete human being. "Be yourself" is not always possible and often people are forced to be nonauthentic and pretend something else. The identity includes mainly the identification with roles. However, another aspect of identity can be citizenship, property, social class, occupation etc. The identification is the source of self-evaluation and self-presentation [2].

For further definition, more suitable for other disciplines the identity can be defined as "In psychology, it is spoken about the consciousness of identity. This is till me, same. Although I change. Meanwhile, consciousness is a sign of normality. In developmental psychology, the process of searching for identity is seen as an element of adulthood. The adolescent often questions themselves such as Who am I? Am I an adult? The identity in this sense is what investigated by E. H. Erikson (1955). Also, humanistic psychology highlights the identity and process of searching for it. Humanistic psychology understands it as the ability to be who you are. This field is more in-depth described by A. H. Maslow (1954) and he links it with the will to self-realize. In anthropology, identity is mentioned as living in truth, level of integration yourself, and your role. The most significant influence can be seen in sociology where identity was investigated by R. G. Dahrendorf (1950) and E. Goffman (1959) mainly in Shakespeare and his thesis human-actor. The question in what level a human can be considered as authentic in their roles and false in auto presentation."

For purpose of this text is adequate to use the definition from Matějček [3] who includes identity as a primary human psychological need and sees it as important for gaining social value and social 
placement. From gaining the identity rise the health consciousness of myself and self-acceptance.

"The questions for building stable identity are part of all professions. Professional identity or collective identity is one of the three identity types (next to selfidentity and group identity), which are closely linked together. Moreover, the need for identity is one of the main five psychological needs. Identity is some inner process which people use to compare themselves with other" [4].

Thus, identity should be seen as a source for motivation, which can influence social interaction such as:

- Inner responsibility to define relationships with surroundings;

- own right which drives needs and interests;

- reasonings and actions;

- a tool to control reality and correlate with the creation of self-respect.

Term identity is well known, and people use it in everyday life. However, after defining the term we can see that it is more complex and the importance of identity in human life is significant.

Definition of collective identity can be seen as "collective self-understanding of people, who claims it is important to observe goals and use specific tools and strategies for a profession" [5]. "Common goal is an important aspect of professional identity. The workers can have diverse motivations, attitudes. However, they should adore one goal, towards which their profession is heading, and they should feel the urge to be in this professional group. Also, they should feel the need to differ from other groups" [6].

"Discussion about professional identity can be led towards two different directions. The first direction is towards understanding professional identity as part of a worker's social identity, which interacts with their understanding and other outside influences. The second direction is towards the question 'what is social work?'. More likely what are the specific aspects which differ this profession from other helping professions" [7].

One of the explanatories approached toward professional identity presents Mareš [8]. He has adjusted the work of Kelchtermans, who divided a teacher's professional identity into three dimensions:

1. The retrospective dimension of professional identity is divided to:

- self-picture, self-respect, self-evaluation;

- professional motivation;

- understanding of a task.

2. Current me, who has the same dimension as retrospective me, present in present.
3. Prospective dimensions of professional me are understood as professional perspective:

- my professional career;

- future paths of my pupils;

- the perspective of our school.

Strengthening of professional identity is an ongoing process of realizing own professionality. This means notifying myself in a teacher role, need of autonomy, initiatives for equal responsibility amount, the equal need of self-control, and bigger amount of self-engagement [9].

The professional identity is closely linked with professional ethics, consistent familiarizing with professional ethos and values has practical meaning for the pedagogical worker also. Thus, it can help to stop and think about values that are required for the profession [10].

The professional identity is linked and created by basic identity also. However, another crucial element is a professional ethic which is connected to professionality. In relation to the topic of this paper it is important to mention the legal dimensions also. "... nowadays intensions in history of democratic and legal states introduce demand for citizens' active participation is the creation of legal stable environment and legal security in relation towards the human right and freedom protection. There are created complicated frameworks that should guarantee the full and non-district performance of human rights and freedom. Plus, the fulfilment of human/citizen duties." [11].

The student's achievement and furthermore the professional performance is related to the evaluation which can a student experience at placement. There are methods for assessing the employees which are based on diverse aspects and rules, which use different principles and criteria. Of course, each method has pros and cons. Methods of assessment can be divided into groups based on their focus, areas of assessment, or time diversity. The first assessment an employee experiences when they are applying for the job [12].

\section{Research Survey}

The questionnaire survey was part of the exploratory project of the School of Special Pedagogy "The exploratory analysis of a strategy to solve and realize pedagogical placement at the School of Special Pedagogy". The aim of the analysis was to draw on the view of undergraduate students at the School of Special Pedagogy at the University Jan Amos Komensky Prague s.r.o. Thus, it is to highlight the students' opinion on professional identity in the context of placement which is conducted during their studies. 
Furthermore, other aims were established:

- To elicit sociodemographic structure of students at the School of Special Pedagogy.

- To chart students' motivation for choosing their major and future career;

- To describe the relationship between practice and professional identity.

\section{Data Collection}

The method for data collection was a questionnaire. It is often used method in the pedagogical, sociological, and psychological fields. A questionnaire is used to collect information, perspectives, and ideas about a topic. According to Chrásky [13], a questionnaire is a process of asking or written questions and receiving written answers. It is a list of in advance prepared questions that are organized in an elaborate system. Thus, the questions are answered in written form by a respondent. Plus, this method allows a researcher to collect a bigger amount of data [14]. Every respondent has received the same set of questions, and this is important for assessing the results. Another advantage of the chosen method is the easier and quicker way of data collection. Also, the respondent can answer more personal questions which could be inappropriate in personal contact. The reason for choosing a questionnaire was the ability to gain more diverse respondents. The respondents were students at the University of Jan Amos Komesky Prague s.r.o. and mainly from the School of Special Pedagogy, who study undergraduate courses Special Pedagogy or Re-socializing and penitentiary pedagogy either fulltime or part-time. The questionnaire included open and closed questions. The pilot testing was conducted; thus, some changes were made in formulating the questions. The questionnaire was provided online throughout the Microsoft forms from November 2020 till February 2021. Overall, 628 students were asked to participate and 501 has answered. Thus, $80 \%$ of respondents took part, which we consider as a significant achievement.

By coding and description of output data file transforming output data file i.e., cleaning the data, transforming, and coding value of all transfiguration was created outputting data file. The data file is customs' friendly and whether it is needed it can be further used or expanded. The outputting data file was analyzed. Basic frequencies were discovered by descriptive analysis and relations between transfigurations. Furthermore, the results were presented in form of tables and figures. Thus, the results in this paper are presented here and they are from this questionnaire.

\section{Results}

\section{Sociodemographic Structure of Students}

The questionnaire was filled out by 501 students including 41 men (8\%) and 459 females (92\%). The age pyramid in figure 1 "Respondents' structure based on age and gender" presents respondents' age layout. Only one-third of students at levels 1-3 are under 26 years. The other two-thirds are older, $6 \%$ is in age 42 years. Almost $5 \%$ is older than 50 years. The average students' age is 33 years. Thus, the average and the median age of students at special pedagogy major is higher. The age median which separates students' population equal in half is in the case of special pedagogy students for 6 years higher than within students of re-socializing and penitential pedagogy (34 vs. 24 years).

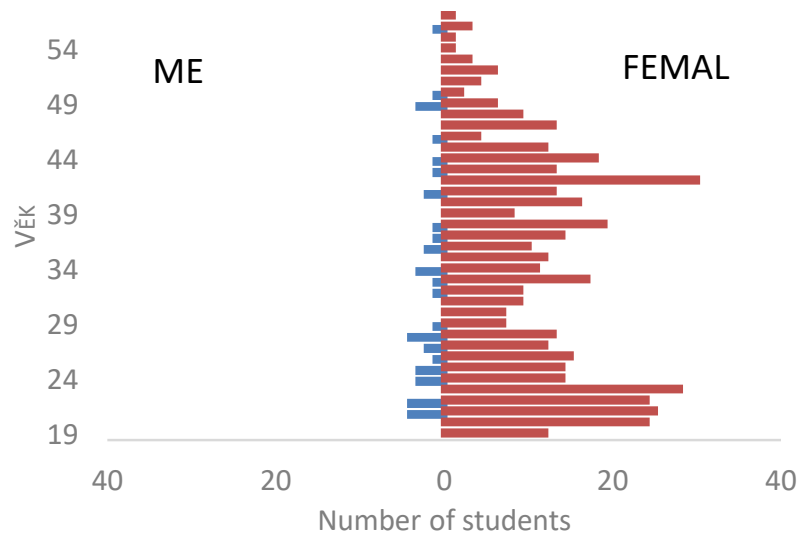

Figure 1. Respondents' structure based on age and gender (own data processing)

Based on Figure 1, it is obvious that the study at these majors is not attractive only for high school graduates, moreover for middle-aged workers who might need to supplement their education while working. This statement is supported by Table 2 "Respondents' structure based on their motivation for studies and motivation for the choice of their profession". Similarly, the structure of respondents based on their achieved education shows one-fifth of students have studied as a form of continuing studies. The biggest part $59 \%$ of respondents graduated from specialized high school. Plus, most of the respondents (92\%) study Special pedagogy majors, and only $8 \%$ of respondents study Re-socializing and penitential pedagogy majors. It is important to highlight that the Re-socializing and penitential pedagogy is a new course offered since 2019. Whereas the Special Pedagogy major has tradition and history. Half of the respondents are at the $1 \mathrm{st}$ level, more than one-fourth is at the 2nd level, and $22 \%$ is at the 3 rd level of their studies. 
Table 1. Respondents' structure based on their achieved education, major and level of study (own data processing)

\begin{tabular}{|c|c|c|}
\hline Achieved education & Abs. & $\%$ \\
\hline Specialized high school & 293 & 58,5 \\
\hline High school & 100 & 20,0 \\
\hline $\begin{array}{l}\text { Specialized college or extra year to gain } \\
\text { A-levels }\end{array}$ & 87 & 17,4 \\
\hline Undergraduate course (Bachelor) & 10 & 2,0 \\
\hline Postgraduate course (Mgr., Ing.) & 11 & 2,2 \\
\hline Full postgraduate (Ph.D.) & 0 & 0,0 \\
\hline \multicolumn{3}{|l|}{ Major } \\
\hline Special pedagogy & 461 & 92,0 \\
\hline Re-socializing a penitential pedagogy & 40 & 8,0 \\
\hline \multicolumn{3}{|l|}{$\begin{array}{c}\text { Level } \\
\end{array}$} \\
\hline I. & 258 & 51,5 \\
\hline II. & 133 & 26,5 \\
\hline III. & 110 & 22,0 \\
\hline
\end{tabular}

\section{Motivation for Studies and the Choice of their Profession}

The questionnaire asked for respondents' motivation to study their major and their motivation for the chosen profession also. As shown in Table 2 'Respondents' structure based on their motivation for studies and motivation for the choice of their profession" almost half of the students have decided to study this major to increase their education and qualification and almost one-third to increase their knowledge and orientation in their field. More than $6 \%$ of respondents have chosen their professional identity creation as their main motivation. To increase their financial income, only 5 respondents were chosen $(1 \%)$ and better position at job market have chosen only 2 students $(0,5 \%)$. Also, it is interesting to investigate the motivation for the chosen profession (Table 2, second part). The categories are more equal than in motivation for studies. The biggest group of respondents $34 \%$ have chosen this major to be able to help and support the major's target group. Almost one-fourth of students identify these majors as professional interesting. For $18 \%$ of students, the most significant motivation is the need to enrich their education to be able to work in their current workplace. The personal experience with target group from family or close friends have $18 \%$ of respondents.
Table 2. The structure of respondents according to motivation to study and motivation to choose a given profession (own data processing)

\begin{tabular}{|c|c|c|}
\hline Motivation for studies & Abs. & $\%$ \\
\hline to increase qualification & 244 & 48,7 \\
\hline $\begin{array}{l}\text { to gain more knowledge and orientation } \\
\text { in field }\end{array}$ & 154 & 30,7 \\
\hline impulse for further studies & 39 & 7,8 \\
\hline creation of professional identity & 32 & 6,4 \\
\hline $\begin{array}{l}\text { development of personal qualities in life- } \\
\text { long education }\end{array}$ & 21 & 4,2 \\
\hline increase of finance income & 5 & 1,0 \\
\hline getting to know more people in the field & 2 & 0,4 \\
\hline better position at job market & 2 & 0,4 \\
\hline $\begin{array}{l}\text { personal motivation - family member } \\
\text { with disability }\end{array}$ & 2 & 0,4 \\
\hline \multicolumn{3}{|c|}{ Motivation for choice of this profession } \\
\hline $\begin{array}{l}\text { motivation to help and support target } \\
\text { group of these majors }\end{array}$ & 169 & 33,7 \\
\hline $\begin{array}{l}\text { professionally interesting work which I } \\
\text { would like to do }\end{array}$ & 119 & 23,8 \\
\hline $\begin{array}{l}\text { need to increase the level of achieved } \\
\text { education }\end{array}$ & 91 & 18,2 \\
\hline $\begin{array}{l}\text { personal experience with target group } \\
\text { from family }\end{array}$ & 89 & 17,8 \\
\hline $\begin{array}{l}\text { previous volunteering or charity } \\
\text { experience }\end{array}$ & 18 & 3,6 \\
\hline this a field where I can always find a job & 12 & 2,4 \\
\hline ofessional prestige & 3 & 0,6 \\
\hline media influence & 0 & 0,0 \\
\hline
\end{tabular}

Another question which was in the questionnaire was a student's evaluation of personal assumptions. Almost half of the students identified empathy as the most important personal quality (47\%). As Figure 2 "Evaluation of student's personal assumptions at these majors" shows not any other personal quality was identified as often as empathy. The second most important was social awareness which was identified by $24 \%$ of respondents. The third was the ability to solve problematic situations and conflicts (24\%). Nevertheless, responsibility, communication, consistency, and teamwork are important as well.

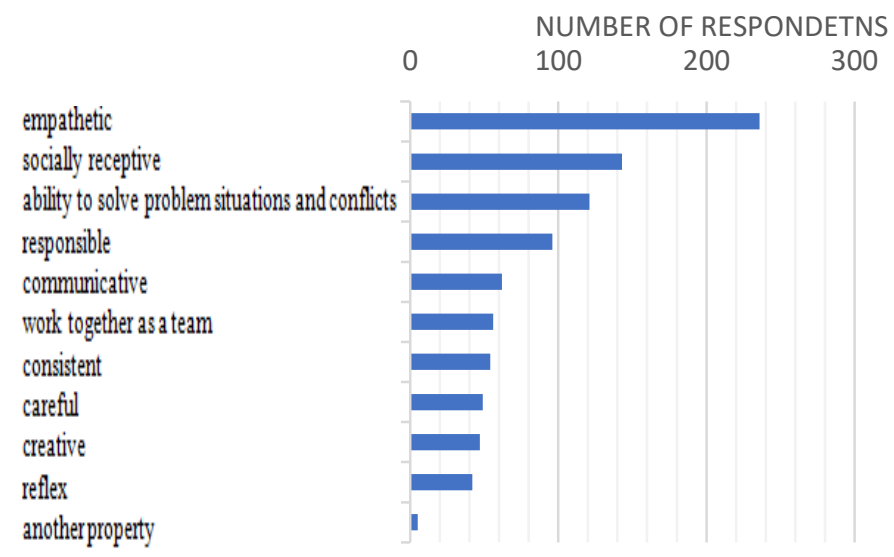

Figure 2. Evaluation of student's personal assumptions at these majors (own data processing) 


\section{Professional Identity}

Some of the questions were asked about professional identity. Most of the students recognize the influence of placement on their creation of professional identity. Only $20 \%$ of respondents think that placement does not influence the creation of professional identity (figure 3 "Understanding influence of placement on the creation of professional identity").

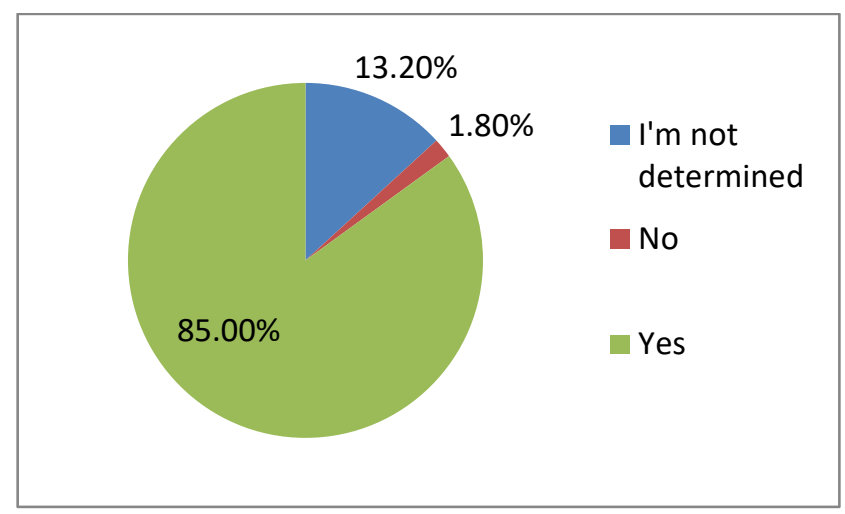

Figure 3. Understanding influence of placement on the creation of professional identity (own data processing)

However, more than four-fifths are convinced about the importance of professional identity for their studies and future career. None of the respondents does think that professional identity is not important (Figure 4 "The importance of professional identity).

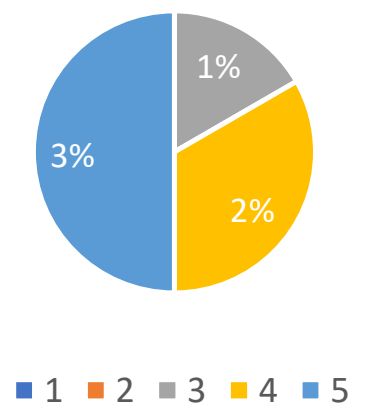

Figure 4. The importance of professional identity $(1=$ not at all; $5=$ very important) (own data processing)

In relation to studies the professional identity means for $40 \%$ of respondent professional level of knowledge, abilities, and experiences. For almost one-third of respondents the professional identity means positive relationship towards their work with high level of expertise and human approach towards target group. For rest of the respondents the professional identity means personal approaches, goals in their profession, or moral and other values (see Table 3 "The meaning of professional identity with regards to studies").
Table 3. The meaning of professional identity with regards to studies (own data processing)

\begin{tabular}{|c|c|c|}
\hline $\begin{array}{c}\text { The meaning of professional identity } \\
\text { with regards to studies }\end{array}$ & Abs. & $\%$ \\
\hline $\begin{array}{l}\text { Professional level of expertise, } \\
\text { knowledge and abilties }\end{array}$ & 203 & 40,5 \\
\hline $\begin{array}{l}\text { Positive attitude towards work and high } \\
\text { level of human approach }\end{array}$ & 162 & 32,3 \\
\hline Own attitude and goal in the profession & 45 & 9,0 \\
\hline $\begin{array}{l}\text { Achieved education and quality } \\
\text { placement }\end{array}$ & 43 & 8,6 \\
\hline Moral and other values & 17 & 3,4 \\
\hline Adequate set of boundaries & 11 & 2,2 \\
\hline $\begin{array}{l}\text { Multidisciplinary and cooperation with } \\
\text { colleagues }\end{array}$ & 11 & 2,2 \\
\hline Increase of social credits in the society & 6 & 1,2 \\
\hline $\begin{array}{l}\text { Recognition of the profession in the } \\
\text { society }\end{array}$ & 3 & 0,6 \\
\hline
\end{tabular}

\section{Employability in the Field}

Figure 5 shows "Employability in the field after successful graduation" significant part of students $85 \%$ are planning to work in their professional field after successful graduation. More than $13 \%$ of respondents are undecided and only $2 \%$ of respondents are not planning to work in the field.

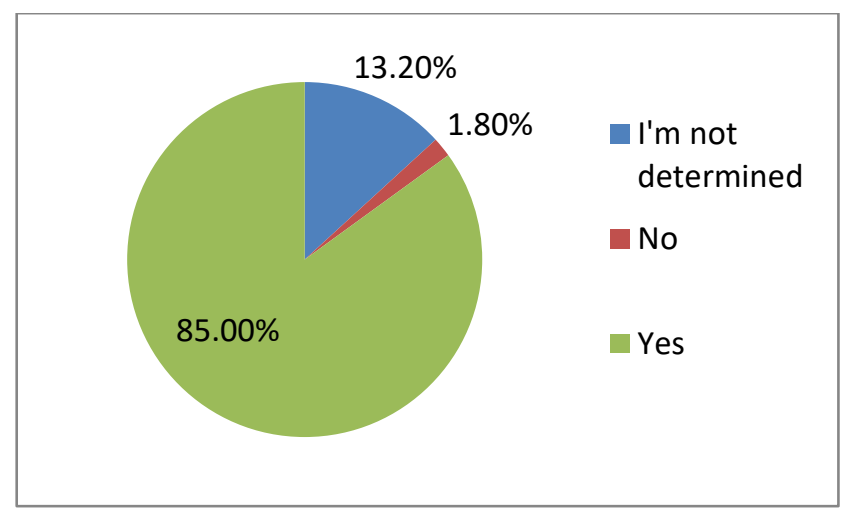

Figure 5. Employability in the field after successful graduation (own data processing)

The students' minimum explains that they are not planning to work in this field because they are increasing their education to be able to work at their current workplace. Plus, some of the respondents are working at primary schools and they want to gain more knowledge about and be able to apply it i.e., during inclusion at their schools.

More than $73 \%$ of students are or plan to do their placement at their current workplace (Table 4). Only $5,5 \%$ of students are working in an institution where they could their placement, but they prefer to do their placement in different provisions. 
Table 4. Students based on their placement in their current workplace (own data processing)

\begin{tabular}{|l|c|c|c|}
\hline Placement at current workplace & Abs. & \% & $\begin{array}{c}\text { \% of } \\
\text { working } \\
\text { students }\end{array}$ \\
\hline $\begin{array}{l}\text { Yes } \\
\begin{array}{l}\text { No, I do not work in this provision } \\
\text { No, I do work in this provision but } \\
\text { during my placement I want to } \\
\text { discover something different }\end{array}\end{array}$ & 238 & 67,5 & 73,8 \\
I am not working while I study & 43 & 8,0 & 20,7 \\
\hline \multicolumn{1}{|c|}{ Total } & $\mathbf{5 0 1}$ & $\mathbf{1 0 0 , 0}$ & $\mathbf{1 0 0 , 0}$ \\
\hline \multicolumn{1}{|l|}{} \\
\hline \multicolumn{1}{|l|}{}
\end{tabular}

\section{Relationship Between Placement and Professional Identity}

The following aim was to describe are advantages of placement from students' view. Students assessed criteria and they have assigned them the level of importance. The average students have identified the level of practical abilities. Almost two-thirds of students have agreed that this is a very important factor.

95\% of students see placement as a crucial part of their studies. The professional identity identifies $85 \%$ of respondents as an important tool. Also, $76 \%$ of respondents agree with the fact that placement has a significant influence on their creation of professional identity. Therefore, we can ask whether the understanding of professional identity differs based on the level where students study. Based on this, the following question was developed.

$\mathrm{H} 0$ : There are no differences in understanding the importance of placement based on the students' level.

HA: There are differences in understanding the importance of placement based on the students' level.

Firstly, the contingency table of the relationship of the importance of professional identity between the level of studies (Table 5) is followed by construction equal associations.

Table 5. The Contingency relation table of the importance of professional identity based on the level of studies. $(2=$ not important, $5=$ very important $)$. (Own data processing)

\begin{tabular}{|cc|c|c|c|c|c|}
\hline \multirow{2}{*}{$\begin{array}{c}\text { Level of } \\
\text { studies }\end{array}$} & \multicolumn{4}{|c|}{$\begin{array}{c}\text { The importance of } \\
\text { professional identity }\end{array}$} & \multirow{2}{*}{ Total } \\
\cline { 3 - 6 } & 2 & 3 & 4 & 5 & \\
\hline \multirow{2}{*}{1} & Quantity & 4 & 30 & 101 & 123 & 258 \\
& $\%$ & $1,6 \%$ & $11,6 \%$ & $39,1 \%$ & $47,7 \%$ & $100,0 \%$ \\
\hline \multirow{2}{*}{2} & Quantity & 3 & 21 & 57 & 52 & 133 \\
& $\%$ & $2,3 \%$ & $15,8 \%$ & $42,9 \%$ & $39,1 \%$ & $100,0 \%$ \\
\hline \multirow{2}{*}{3} & Quantity & 2 & 17 & 38 & 53 & 110 \\
& $\%$ & $1,8 \%$ & $15,5 \%$ & $34,5 \%$ & $48,2 \%$ & $100,0 \%$ \\
\hline \multirow{2}{*}{ Total Quantity } & 9 & 68 & 196 & 228 & 501 \\
& $\%$ & $1,8 \%$ & $13,6 \%$ & $39,1 \%$ & $45,5 \%$ & $100,0 \%$ \\
\hline
\end{tabular}

As we can observe in the contingency Table there are no visible differences in understanding the importance of professional identity across the levels of studies. Also, the counted chi-quadrat $=4,43$ neither significance $=0,618$ do not allow the total rejection of hypothesis. Therefore, we can accept the zero hypothesis and claim, that there are not any differences in understanding the importance of placement while studies.

However, it is possible that professional identity is created by age or the lower level of studies, and by placement can be meant the professional placement which can a student has done somewhere else, too. Thus, a new zero hypothesis will be made:

H0: There are not any differences in understanding the importance of placement based on students' age.

HA: There are differences in understanding the importance of placement based on students' age.

The new contingency table was calculated and equal values of association were calculated also (Table 6).

Table 6. The contingency table of relationship between students' age and professional identity ( 2 = not important; $5=$ very important). (Own data processing)

\begin{tabular}{|c|c|c|c|c|c|}
\hline \multirow{2}{*}{ Students' age } & \multicolumn{4}{|c|}{$\begin{array}{c}\text { The importance of } \\
\text { professional identity }\end{array}$} & \multirow{2}{*}{$\stackrel{\widetilde{\pi}}{\ominus}$} \\
\hline & 2 & 3 & 4 & 5 & \\
\hline \multirow{2}{*}{$\begin{array}{cc}\text { TO 24 } & \text { quantity } \\
\text { years } & \%\end{array}$} & 4 & 24 & 61 & 49 & 138 \\
\hline & $2,9 \%$ & $17,4 \%$ & $44,2 \%$ & $35,5 \%$ & $100,0 \%$ \\
\hline \multirow{2}{*}{$\begin{array}{l}25-33 \\
\text { years }\end{array}$} & 2 & 15 & 47 & 52 & 116 \\
\hline & $1,7 \%$ & $12,9 \%$ & $40,5 \%$ & $44,8 \%$ & $100,0 \%$ \\
\hline $\begin{array}{l}34-42 \\
\text { years }\end{array}$ & 3 & 16 & 52 & 71 & 142 \\
\hline years & $2,1 \%$ & $11,3 \%$ & $36,6 \%$ & $50,0 \%$ & $100,0 \%$ \\
\hline $\begin{array}{l}43 \text { years } \\
\text { and more }\end{array}$ & 0 & 13 & 36 & 56 & 105 \\
\hline and more & $0,0 \%$ & $12,4 \%$ & $34,3 \%$ & $53,3 \%$ & $100,0 \%$ \\
\hline quantity & 9 & 68 & 196 & 228 & 501 \\
\hline Ootal & $1,8 \%$ & $13,6 \%$ & $39,1 \%$ & $45,5 \%$ & $100,0 \%$ \\
\hline
\end{tabular}

In this combination, chi-quadrat reaches higher values $(=12)$. However, the significance does not reach enough high value $(=0,214)$. Therefore, the zero hypotheses cannot be accepted. However, the chi-quadrat is sometimes too harsh solution, and it cannot identify some relations. Thus, it is important to acknowledge other indexes. In this case, all other indexes which indicate relations between two ordinal transfigurations accomplish favourable values (Somers' d, Kendalls' tau, and Gamma have calculated values more favourable values of testes statistic $=0,002$ ). Therefore, the zero hypothesis can be rejected, and it can be claimed that there are differences in understanding the importance of placement based on students' age. 


\section{Conclusion}

Nowadays, placement is a more significant part of studies not only in employability but in the international perspective of improving educational quality mainly, by highlighting the need for practical training at diverse provisions. A placement helps with the creation and development of a professional identity. Therefore, the attention to professional identity was paid because single moments, experiences, abilities, feelings, reflections, and other aspects which students experience can help or harm one in their professional career and future employability. Thus, a placement is a place for applying theoretical knowledge and realizing whether the student made the right choice to study their major. Also, it can be seen as motivation for those who are not studying types to finish their studies, so they will be able to do their profession.

Development and quality of placement is not the only result of university but a student who is representing university also. A placement is a place where a student can open the door for other students to do the same placement. A permanently developing portfolio of cooperating institutions on diverse activities such as projects, conferences, and expert seminars generates knowledge of professions' multifarious. Plus, it generates acknowledgement about cooperation and the ability to share the information which assesses a student, a university, and their expertise.

\section{Acknowledgments}

This research was supported by the Internal Grant Competition, Univerzita Jana Amose komenského Praha s.r.o., IGSO 1/2020.

\section{References}

[1]. Helus, Z. (2007). Sociální psychologie pro pedagogy (Vol. 1). Grada.

[2]. Nakonečný, M. (2009). Psychologie osobnosti. 2. rozšířené a přeprac. vyd. Praha: Academia.

[3]. Matějček, Z. (2008). Co děti nejvíc potřebují (What children need most). Praha: Portal.

[4]. Elichová, M. (2017). Sociální práce: aktuální otázky. Grada.

[5]. Matoušek, O. (2013). Metody a ř́zení sociální práce. Praha: Portál.

[6]. Musil, L. R., \& Růžičková, D. (2009). D. Hledají sociální pracovníci kolektivní identitu. Sociální práce/Sociálna práca 2009, 79-93.

[7]. Šámalová, K. (2016). Šance na dosažení vysokoškolského vzdělání $v$ populaci osob se zdravotním postižením. Charles University in Prague, Karolinum Press.

[8]. Mareš, J. (2013). Pedagogická psychologie. Praha: Portál, 702 s. ISBN 978-80-262.

[9]. Lukášová, H. (2015). Učitelské sebepojetí a jeho zkoumání. Univerzita Tomáše Bati ve Zlíně.

[10]. Stárek, L., Klugerová, J., \& Buchtová, E. (2021). Vybrané aspekty ovlivňující edukační proces dítěte.

[11]. Stárek, L., \& Klugerová, J. (2021). Model odborné praxe a charakteristika studentů katedry speciální pedagogiky. Štúdie zo špeciálnej pedagogiky, 10(2), 108-124.

[12]. Zpěvák, A., Kohout, M., Víšek, J., \& Fiala, Z. (2016). The Importance of Personnel Evaluation Activities of the Armed Forces-Evaluation Methods, Taking Into Account Certain Aspects of Czech Private Law. Internal Security, 8(2), 7-18. DOI: $10.5604 / 01.3001 .0010 .2267$

[13]. Chráska, M. (2007). Metody pedagogického výzkumu. grada Publishing as.

[14]. Punch, K. F. (2008). Základy kvantitativního šetření. 1. vydání. Praha. Portál, 152. 